\title{
OTR12 - GESTÃo DA MUDANÇA EM ÁREAS DE SUPORTE ÀS INSTITUIÇÕES DE CIÊNCIA E TECNOLOGIA
}

\author{
$\underline{\text { Jorge de Oliveira Teixeira Junior }}^{1}$
}

1. Bio-Manguinhos, Fundação Osvaldo Cruz, Gestão, Rio de Janeiro, Brasil

Objetivo: Apresentar metodologia para gestão da mudança em áreas basais de suporte às organizações.

Metodologia: Estudo de caso da reestruturação da Seção de Apoio de Bio-Manguinhos. Gestão da mudança nesse setor possibilitou o desenvolvimento de metodologia aplicável a áreas basais da Administração Pública carentes de razoável nível de entrega de serviços. Ficou evidenciada a baixa aderência da efetividade da Seção aos objetivos organizacionais, constatando-se o descumprimento de critérios como agilidade, presteza, compromisso, assiduidade. Diagnóstico demonstrou necessidade de planos de ação leves e sucintos, com etapas breves e facilmente replicáveis em períodos de curta duração. Estruturação desses planos envolveu levantamentos para o profundo conhecimento sobre os funcionários e seu posicionamento como proprietários dos processos. Foram realizados benchmarkings com stakeholders, buscando referências para: adoção de melhores práticas; levantamento dos custos de cada atividade; estabelecimento de SLA; criação de Guia de Serviços; melhora na avaliação por parte dos clientes.

Resultados: Reforço da importância da validação dos novos gestores pela alta administração e demonstra cão da relevância da utilização de ferramentas e tecnologias de informação para responder rapidamente ao ritmo vertiginoso das mudanças organizacionais. Destaque do grande valor da comunicação constante entre gestor e equipe para alinhar expectativas e atuações aos objetivos organizacionais. Evidência da necessidade de manutenção das equipes em contínua atividade, em nível adequado de orientação para resultados. Envolvimento dos colaboradores no planejamento da área, desenvolvendo análise ambiental de maneira a permitir a identificação de fatores críticos, a proposição de ações para a reestruturação. Atualização das descrições das atividades de cada processo de trabalho; elaboração de instruções de trabalho que formalizaram rotinas da área. Ambiente e processos de trabalho aprimorados através técnicas de eliminação de 
papéis, diminuição do volume de documentos, digitalização. Descrição da missão da área; discriminação dos principais fornecedores e clientes; arrolamento de estruturas, recursos, equipamentos, materiais necessários ao trabalho; construção de indicadores para a medição dos processos de trabalho; desenho dos fluxos das rotinas de trabalho. Lacunas em conhecimentos, habilidades e atitudes minimizadas; equipe treinada e desenvolvida por meio de oportunidades internas e gratuitas de treinamento, parcerias com outras unidades, instituições e órgãos, públicos ou privados, além de opções online. Foco em RH levou à melhoria dos processos, permitindo a apresentação de proposta para redução de gastos; alteração da estrutura de cargos e salários para o exercício seguinte, processos de trabalho escritos e desenhados; melhora na avaliação dos stakeholders; Acordos de Nível de Serviço estabelecidos com os principais clientes; Guia de Serviços oficializado; Plano de Cargos e Salários estruturado; Centros de Custos determinados.

Conclusão: A metodologia, construída como um guia para novos gestores implantarem a gestão da mudança em seis meses em áreas basais do serviço público, demonstra-se prática e aplicável também em instituições de Ciência e Tecnologia. 